\title{
Frequency of the Q192R and L55M polymorphisms of the human serum paraoxonase gene (PON1) in ten Amazonian Amerindian tribes
}

\author{
Ney Pereira Carneiro dos Santos ${ }^{1}$, Ândrea KC Ribeiro-dos-Santos ${ }^{1}$ and Sidney EB Santos ${ }^{1}$ \\ ${ }^{1}$ Universidade Federal do Pará, Laboratório de Genética Humana e Médica, Belém, Pará, Brazil.
}

\begin{abstract}
Human serum paraoxonase (PON1) is an esterase associated with high density lipoproteins (HDLs) in the plasma and may confer protection against coronary artery disease. Serum PON1 levels and activity vary widely among individuals and populations of different ethnic groups, such variations appearing to be related to two coding region polymorphisms (L55M and Q192R). Several independent studies have indicated that the polymorphism at codon 192 (the R form) is a significant risk factor for cardiovascular disease in some populations, although this association has not been confirmed in other populations. Given the possible associations of these mutations with heart diseases and the fact that little or nothing is known of their prevalence in Amerindian populations, we investigated the variability of both polymorphisms in ten Amazonian Indian tribes and compared the variation found with that of other Asian populations in which both polymorphisms have been investigated. The results show that the $L R$ haplotype is the most frequent and the $M R$ haplotype is absent in all Amerindians and Asian populations. We also found that South America Amerindians present the highest frequency of the PON1192* $R$ allele (considered a significant risk factor for heart diseases in some populations) of all the Amerindian and Asian populations so far studied.
\end{abstract}

Key words: human serum paraoxonase, populations genetics, Amerindian, PON1, Amazonian populations.

Received: January 21, 2004; Accepted: August 18, 2004.

\section{Paraoxonase polymorphisms in Amazonian Amerindians}

Human serum paraoxonase (PON1) is an esterase associated with serum high-density lipoproteins (HDLs) and is coded by a gene located on the 7q21.3-22.1 region of chromosome 7 in a cluster with two similar genes, PON2 and PON3 (Primo-Parmo et al., 1996). The PON1 protein has been found to be involved in the detoxification of organophosphate insecticides such as parathion and the neural agents soman and sarin (Davies et al., 1996) but PON1 may also confer protection against coronary artery disease by destroying pro-inflammatory oxidized lipids present in oxidized low density lipoproteins (Mackness et al., 1998).

The PON1 coding region contains two common polymorphisms, a leucine (L) to methionine (M) substitution at codon $55(\mathrm{~L} 55 \mathrm{M})$ and a glutamine $(\mathrm{Q})$ to arginine (R) substitution at codon 192 (Q192R). These polymorphisms are only $8.6 \mathrm{~Kb}$ apart from each other (Gen Bank accession number AC004022). By the direct sequencing of the PON1 gene in orangutans and chimpanzees, Koda et al. (2004)

Send correspondence to Sidney Emanuel Batista dos Santos, Departamento de Patologia, Centro de Ciências Biológicas, Universidade Federal do Pará, Caixa Postal 8615, 66.075-970, Belém, Pará, Brasil. E-mail: akely@ufpa.br. showed that the allele which codifies arginine in the 192 codon $(P O N 1192 * R)$ is the ancestor allele in human populations.

Serum PON1 levels and activity varies widely among individuals and populations of different ethnic groups and seems to be related to the Q192R and L55M polymorphisms, with individuals bearing the 192R isoform having higher PON1 activity than those with the 192Q isoform (Garin et al., 1997).

Several independent studies have indicated that the polymorphism at codon 192 (the $\mathrm{R}$ form) is a significant risk factor for cardiovascular disease in some populations (Serrato and Marian, 1995; Sanghera et al., 1998a; Durrington et al., 2001; Aynacioglu and Kepekci 2000; Imai et al., 2000; Gnasso et al,. 2002), although this association has not been confirmed in other populations (Antikainen et al., 1996; Herrmann et al., 1996; Suehiro et al., 1996; Garin et al., 1997; Ombres et al., 1998). A possible explanation for this inconsistent association is that the codon 192 polymorphism is related to risk of cardiovascular disease only when it is associated with other mutation(s) in a particular haplotype (Koda et al., 2004).

Given the possible associations of these mutations with cardiovascular diseases and the fact that little or nothing is known of the prevalence of these mutations in Amer- 
indian populations we investigated the frequency of the Q192R and L55M polymorphisms in ten Amazonian Indian tribes in which heart disease is rare, possibly because of their non-urban lifestyle, and compared the variation found with that of other Asian populations to estimate if the allele frequencies differ significantly.

Between 1983 and 1990 our team studied 259 putatively unrelated individuals from ten tribes with distinct linguistic and cultural backgrounds (Poturujara; Mapuera; Wayampi; Arara; Parakanã; Assurini of Koatinemo; AwáGuajá; Yanomami; Urubu-Kaapor and Kayapo) which were distributed over a large geographic area of the Brazilian Amazon. Additional data on the genetic and linguistic characterization of theses groups have been published previously (Silva Jr. et al., 2002; Ribeiro-dos-Santos et al., 2001; Vallinoto et al., 1999; Santos et al., 1998). This research was approved by the ethical committee of the Federal University of Pará, Brazil.

Genomic DNA was isolated from whole blood by the salting out method of Miller et al. (1998) and the method described by Motti et al. (2001), with some modifications, was used to simultaneously determine the three most common polymorphisms of the PON cluster (PON1-192, PON1-55 and PON2-311) using a multiplex polymerase chain reaction (PCR) DNA assay with mismatch primers to introduce a unique recognition site for the Hinf I endonuclease in the PCR products when the $P O N 1 * 192 R$ or $P O N 1 * 55 \mathrm{~L}$ alleles are present. Our study did not involve the PON2 polymorphisms.

The multiplex-PCR was performed in a $15 \mu \mathrm{L}$ reaction mixture containing $100 \mathrm{ng}$ of the template DNA amplified using an initial step of $94{ }^{\circ} \mathrm{C}$ for 2 min followed by 30 cycles for $30 \mathrm{~s}$ at $94^{\circ} \mathrm{C}, 45 \mathrm{~s}$ at $60^{\circ} \mathrm{C}$ and $45 \mathrm{~s}$ at $72{ }^{\circ} \mathrm{C}$, with a final extension of $5 \mathrm{~min}$ at $72^{\circ} \mathrm{C}$. The total product of the Multiplex-PCR amplification $(15 \mu \mathrm{L})$ was digested overnight at $37{ }^{\circ} \mathrm{C}$ with $5 \mathrm{U}$ of Hinf I (Boehringer Mannheim, Monza, Italy) in a total volume of $25 \mu \mathrm{L}$, the digestion products being separated by polyacrylamide gel $(9 \% \mathrm{w} / \mathrm{v})$ electrophoresis and stained with silver.

Allele and haplotype frequencies were computed using an expectation-maximization (EM) algorithm (Excoffier and Slatkin, 1995) and the Hardy-Weinberg equilibrium and linkage disequilibrium evaluated by the exact test using the Markov chain method (Slatkin and Excoffier, 1996). Comparisons between populations were performed using the exact test for sample differentiation based on haplotype frequencies (Raymond and Rousset, 1995). All evaluations were performed using the ARLEQUIN computer program (Schneider et al., 2000).

Table 1 shows the combined genotype and allele frequencies of the two PON1 gene polymorphisms (L55M and Q192R) in the ten tribes. In the Poturujara tribe only the $P O N 1 * 55 L$ and $P O N 1 * 192 R$ alleles were found but In the majority of the tribes (Mapuera, Waiampi, Arara, Awa-Guajá, Assurini, Urubu-Kaapor) only the $P O N 1 * 55 L$
Table 1 - Combined frequencies of the L55M and Q192R polymorphisms and the allele frequencies observed in ten Amazonian Amerindian tribes.

\begin{tabular}{|c|c|c|c|c|c|c|c|c|}
\hline Tribes & $\mathrm{N}$ & $\begin{array}{l}L L \\
R R\end{array}$ & $\begin{array}{l}L L \\
Q R\end{array}$ & $\begin{array}{l}L L \\
Q Q\end{array}$ & $\begin{array}{l}L M \\
Q R\end{array}$ & $\begin{array}{l}L M \\
Q Q\end{array}$ & $L$ & $R$ \\
\hline Poturujara & 47 & 47 & 0 & 0 & 0 & 0 & 1.0 & 1.0 \\
\hline Mapuera & 29 & 13 & 13 & 3 & 0 & 0 & 1.0 & 0.672 \\
\hline Parakanã & 17 & 7 & 3 & 3 & 1 & 3 & 0.882 & 0.529 \\
\hline Wayampi & 16 & 11 & 5 & 0 & 0 & 0 & 1.0 & 0.844 \\
\hline Arara & 35 & 22 & 11 & 2 & 0 & 0 & 1.0 & 0.786 \\
\hline Awá-Guajá & 28 & 12 & 14 & 2 & 0 & 0 & 1.0 & 0.679 \\
\hline $\begin{array}{l}\text { Assurini } \\
\text { Koatinemo }\end{array}$ & 15 & 5 & 9 & 1 & 0 & 0 & 1.0 & 0.633 \\
\hline Urubu-Kaapor & 26 & 10 & 12 & 4 & 0 & 0 & 1.0 & 0.615 \\
\hline Yanomami & 19 & 4 & 6 & 1 & 1 & 7 & 0.789 & 0.395 \\
\hline Kayapo & 27 & 16 & 7 & 1 & 3 & 0 & 0.944 & 0.778 \\
\hline Total & 259 & 147 & 80 & 17 & 5 & 10 & 0.971 & 0.732 \\
\hline
\end{tabular}

allele was observed. The $P O N 1 * 55 M$ allele is present in the heterozygous form in individuals from the Parakanã, Yanomami and Kaiapo tribes at frequencies of between $6 \%$ and $21 \%$. Considering all subjects, the observed frequencies were $P O N 1 * 55 L=0.97$ and $P O N 1 * 55 M=0.03$. In the majority of the tribes, the frequency of the $P O N 1 * 192 R$ allele is high, varying from 0.53 to 1.000 , except in the Yanomami, which had the highest $P O N 1 * 192 Q$ frequency (0.605). Overall, the observed frequencies were $P O N 1 * 192 R=0.73$ and $P O N 1 * 192 Q=0.27$.

Only five of the nine possible genotypic combinations of the two polymorphisms were recorded, the most common being the $L L / R R$ double homozygote (56\%) followed by the $L L / Q R(31 \%)$, with the $L M / Q R$ double-heterozygote being rare and found only in individuals from the Parakanã, Yanomami and Kayapo tribes. The genotype frequencies for the total Amerindian population were distributed according to a Hardy-Weinberg equilibrium for both the L55M $\left(\chi^{2}=0.19, \mathrm{p}=0.98\right)$ and Q192R $\left(\chi^{2}=3.25, \mathrm{p}=0.211\right)$ polymorphisms.

Table 2 presents the haplotype and allele frequencies observed in general for the Amerindian tribes studied by us and three Asian populations (Chinese (Sanghera et al., 1998b), Korean (Hong et al., 2001) and Japanese (Yamada et al., 2003)) investigated for both polymorphisms. The dis-

Table 2 - Haplotype frequencies of L55M and Q192R polymorphisms in Amazonian Amerindians and three Asian populations.

\begin{tabular}{lccccccc}
\hline Population & $\mathrm{N}$ & $L R$ & $L Q$ & $M R$ & $M Q$ & $L$ & $R$ \\
\hline Amerindians & 259 & 0.730 & 0.237 & - & 0.033 & 0.967 & 0.730 \\
Chinese $^{1}$ & 142 & 0.574 & 0.387 & - & 0.039 & 0.961 & 0.574 \\
Koreans $^{2}$ & 191 & 0.620 & 0.325 & - & 0.055 & 0.945 & 0.620 \\
Japanese $^{3}$ & 2196 & 0.666 & 0.261 & - & 0.073 & 0.927 & 0.666 \\
\hline
\end{tabular}

${ }^{1}$ Sanghera et al., 1998b; ${ }^{2}$ Hong et al., 2001; ${ }^{3}$ Yamada et al., 2003. 
tribution of the PON1*55L allele is relatively homogeneous, with frequencies ranging from $93 \%$ for the Japanese population to $97 \%$ for the Amerindian population, while the $P O N 1 * 192 R$ allele has a broader distribution, ranging from $57 \%$ in Chinese to $73 \%$ in Amerindians.

The $M R$ haplotype is absent in Amerindian and Asian populations, while the $L R$ haplotype occurs at a relatively high frequency in Asian populations, ranging from $57 \%$ in Chinese to $73 \%$ in Amerindians, and the $M Q$ haplotype has a very low prevalence of less than $7 \%$ among Asian populations. The $L Q$ haplotype has the broadest variation of all the haplotypes, ranging from $24 \%$ in Amerindians to $39 \%$ in Chinese.

There are few published data on Amerindian populations with which to compare our results but studies carried out on two Canadian tribes (the Oji-Cree and the Inuit) and the Ecuadorian Cayapa tribe have noted variability in the frequency of the Q192R polymorphism (Hegele, 1999; Hegele et al., 2001; Scacci et al., 2003) with the frequency of the PON1192*R allele being 0.770 for the Oji-Cree, 0.700 for the Inuit and 0.789 for the Cayapa, values similar to the mean value of 0.730 found by us for the Amazonian Amerindians.

The data presented in Table 2 were used to test the linkage disequilibrium (Slatkin and Excoffier, 1996) between the Q192R and L55M loci and to compare all populations by means of the exact test of sample differentiation based on haplotype frequencies (Raymond and Rousset 1995). The tests show that all the loci studied were in linkage disequilibrium $(p<0.001)$ in all populations, such a result being predictable because these two polymorphisms are only $8.6 \mathrm{~Kb}$ apart.

Our comparison shows that the Amerindian population studied by us is different from all other populations ( $p<0.001$, in all comparisons) and that the Japanese population is different from the Korean $(p=0.023)$ and the Chinese $(\mathrm{p}<0.001)$ populations Only the Chinese and Korean populations did not differ statistically $(\mathrm{p}=0.211)$.

Our data show that the distribution of the L55M and Q192R haplotypes of the Paraoxonase 1 gene of the Amazonian Amerindian tribes investigated by us are different from those observed among Asian populations and that Amazonian Amerindians present the highest frequency of the $P O N 1192 * R$ allele, considered a significant risk factor for heart diseases in some, populations of all the Asian populations so far studied.

\section{Acknowledgments}

We thank the Amerindian populations for their collaboration, the Fundação Nacional do Índio (FUNAI) for permission to visit the tribes and for assistance with blood sample collection. This research was supported by Programa de Apoio a Núcleo de Excelência (PRONEX) of Conselho Nacional de Desenvolvimento Científico e Tecnológico (CNPq), Secretaria Executiva de Ciência, Tec- nologia e Meio Ambiente/Fundo Estadual de Ciência e Tecnologia (FUNTEC) and Universidade Federal do Pará (UFPA).

\section{References}

Antikainen M, Murtomaki S, Syvanne M, Pahlman R, Tahvanainen E, Jauhiainen M, Frick MH and Ehnholm C (1996) The Gln-Arg191 polymorphism of the Human paraoxonase gene (HUMPONA) is not associated with the risk of coronary artery disease in finns. J Clin Invest 98:883-885.

Aynacioglu AS and Kepekci Y (2000) The Human paraoxonase Gln-Arg192 (Q/R) polymorphism in Turkish patients with coronary artery disease. Int J Cardiol 74:33-37.

Davies HG, Richter RJ, Keifer M, Broomfield CA, Sowala J and Furlong CE (1996) The effect of the Human serum paraoxonase polymorphism is reversed with diazoxon, soman and sarin. Nat Genet 14:334-336.

Durrington PN, Mackness B and Mackness MI (2001) Paraoxonase and atherosclerosis. Arterioscler Thromb Vasc Biol 21:473-480.

Excoffier L and Slatkin M (1995) Maximum likelihood estimation of molecular haplotype frequencies in a diploid population. Mol Biol Evol 12:921-927.

Garin MCB, James RW, Dussiox P, Blanche H, Passa P, Froguel P and Ruiz J (1997) Paraoxonase polymorphism Met-Leu54 is associated with modified serum concentrations of the enzyme: A possible link between the paraoxonase gene and increased risk of cardiovascular disease in diabetes. J Clin Invest 99:62-66.

Gnasso A, Motti C, Irace C, Di Gennaro I, Pujia A, Leto E, Ciamei M, Crivaro A, Bernardini S, Federici $\mathrm{G}$ and Cortese C (2002) The Arg allele in position 192 of PON1 is associated with carotid atherosclerosis in subjects with elevated HDLs. Atherosclerosis 164:289-295.

Hegele RA (1999) Genetic prediction of atherosclerosis: Lessons from studies in native Canadian populations. Clin Chim Acta 286:47-61.

Hegele RA, Ban MR, Carrington CV and Ramdath DD (2001) Allele frequencies for candidate genes in atherosclerosis and diabetes among Trinidadian neonates. Hum Biol 73:525-531.

Herrmann SM, Blanc H, Poirier O, Arveiler D, Luc G, Evans A, Marques-Vidal P, Bard JM and Cambien F (1996) The Gln/Arg polymorphism of Human paraoxonase (PON192) is not related to myocardial infarction in the ECTIM study. Atherosclerosis 126:299-303.

Hong SH, Song J, Min WK and Kim JQ (2001) Genetic variations of the paraoxonase gene in patients with coronary artery disease. Clin Biochem 34:475-481.

Imai Y, Morita H, Kurihara H, Sugiyama T, Kato N, Ebihara A, Hamada C, Kurihara Y, Shindo T, Oh-hashi Y and Yazaki Y (2000) Evidence for association between paraoxonase gene polymorphisms and atherosclerotic diseases. Atherosclerosis 149:435-442.

Koda Y, Tachida H, Soejima M, Takenaka O and Kimura H (2004) Population differences in DNA sequence variation and linkage disequilibrium at the PON1 gene. Ann Hum Genet 68:110-119. 
Mackness B, Mackness MI, Arrol S, Turkie W and Durrington PN (1998) Effect of the Human serum paraoxonase 55 and 192 genetic polymorphism on the protection by high density lipoprotein against low density lipoprotein oxidative modification. Eur J Biochem 423:57-60.

Miller SA, Dykes DD and Polesky HF (1998) A simple salting-out procedure for extracting DNA from human nucleated cells. Nucl Acid Res 16:1975.

Motti C, Dessi M, Gnasso A, Irace C, Indigeno P, Angelucci CB, Bernardini S, Fucci G, Federici G and Cortese C (2001). A multiplex PCR-based DNA assay for the detection of paraoxonase gene cluster polymorphisms. Atherosclerosis 158:35-40.

Ombres D, Pannitteri G, Montali A, Candeloro A, Seccareccia F, Campagna F, Cantini R, Campa PP, Ricci G and Arca M (1998) The Gln-Arg192 polymorphism of Human paraoxonase gene is not associated with coronary artery disease in Italian patients. Arterioscler Thromb Vasc Biol 18:1611-1616.

Primo-Parmo SL, Sorenson RC, Teiber J and La Du BN (1996) The Human serum paraoxonase/arylesterase gene (pon1) is one member of a multigene family. Genomics 33:498-507.

Raymond M and Rousset F (1995) An exact test for population differentiation. Evolution 49:1280-1283.

Ribeiro-dos-Santos AKC, Guerreiro JF, Santos SEB and Zago MA (2001) The split of the Arara population: Comparison of genetic drift and founder effect. Hum Hered 51:79-84.

Sanghera DK, Aston CE, Saha N and Kamboh MI (1998a) DNA polymorphism in two paraoxonase genes (PON1 and PON2) are associated with the risk of coronary heart disease. Am J Human Genet 62:36-44.

Sanghera DK, Saha N and Kamboh I (1998b) The codon 55 Polymorphism in the Paraoxonase 1 Gene is not Associated with the Risk of Coronary Heart Disease in Asian Indians and Chinese. Atherosclerosis 136:217-223.

Santos SEB, Ribeiro-dos Santos AKC, Guerreiro JF, Santos EJM, Weimer TA, Callegaris-Jacques SM, Mestriner MA, Franco
MHLP, Hutz MH and Salzano FM (1998) New protein genetic studies in six Amazonian Indian populations. Ann Hum Biol 25 (6):505-522.

Scacci R, Corbo RM, Rickards O and De Stefano GF (2003) New data on the world distribution of paraoxonase (PON1 Gln 192 - Arg) gene frequencies. Hum Biol 75:365-73.

Schneider S, Roessli D and Excoffier L (2000) Arlequin Ver 2.0: A Software for population genetics data analysis. Genetics and Biometry Lab, Department of Anthropology, University of Geneva, Switzerland.

Serrato M and Marian, AJ (1995) A variant of Human paraoxonase/arylesterase (HUMPONA) gene is a risk factor for coronary heart disease. J Clin Invest 96:3005-3008.

Silva-Jr WA, Bonatto SL, Holanda AJ, Ribeiro-dos-Santos AKC, Paixão BM, Goldman GH, Abe-Sandes K, RodriguezDelfin L, Barbosa M, Paçó-Larson ML, Petz-Erler ML, Valente V, Santos SEB and Zago MA (2002) Mitochondrial genome diversity of Native Americans supports a single early entry of founder populations into America. Am J Hum Genet 17:187-192.

Slatkin M and Excoffier L (1996) Testing for Linkage Disequilibrium in Genotypic data Using the EM Algorithm. Heredity 76:377-383.

Suehiro T, Nakaichi Y, Yamamoto M, Arii K, Itoh H, Hamashige $\mathrm{N}$ and Hashimoto K (1996) Paraoxonase gene polymorphism in Japanese subjects with coronary heart disease. Int J Cardiol 57:69-73.

Vallinoto ACR, Cayres-Vallinoto IMV, Ribeiro-dos-Santos AKC, Zago MA, Santos SEB and Guerreiro JF (1999) Heterogeneity of Y chromosome markers among Brazilian Amerindians. Am J Hum Biol 11:481-487.

Yamada Y, Ando F, Niino N, Miki T and Shimokata H (2003) Association of polymorphisms of paraoxonase 1 and 2 genes, alone or in combination, with bone mineral density in Community-Dwelling Japanese. J Hum Genet 48:469-475.

Associate Editor: Francisco Mauro Salzano 